ОСНОВЕ УПРАВЉАҢА ПОСЛОВНИМ ПРОЦЕСИМА У ВИСОКОМ ОБРАЗОВАНУ

Лазар Јанић ${ }^{1}$

\title{
BASIS OF MANAGEMENT OF BUSINESS PROCESSES IN HIGHER EDUCATION
}

Lazar Janić

\section{Сажетак}

Већ више од једне деценије, примарна област истраживања је проучавање тржсишне оријентације као институционалног начина за побољшање односа студентуниверзитет. Тржишна оријентаиија је повезана са могућношћу ствараға одрживе супериорне вредности за потрошаче, стварајући на тај начин конкурентску предност, као и виши институционални учинак. Међутим, ниво тржишне оријентације и нивои управљања с нагласком на тржсишне оријентације су алармантно ниски у институичјама високог образовања. Упркос интересу за овај концепт у развијеном свету, високо школство у Србији превиђа да има потребу за променама. Истраживање у овом раду треба да упути на кониепт у смислу конструкиије и начина на који се управљање може применити као успешна стратегија за образовне инстиmуције.

Кључне речи: теорије управљаюа, управљање, академске високошколске установе, струковне високошколске установе.

\section{Summary}

For more than a decade, the primary field of research is the study of market orientation as an institutional way to improve student-university relations. Market orientation is linked to the possibility of creating sustainable superior value for consumers, thus creating a competitive advantage, as well as a higher institutional impact. However, the level of market orientation and levels of governance with an emphasis on market orientations are alarmingly low in higher education institutions. Despite the interest in this concept in the developed world, higher education in Serbia foresees the need for change. The research in this paper should refer to the concept in terms of construction and how management can be applied as a successful strategy for educational institutions.

Key words: management theories, management, academic higher education institutions, vocational higher education institutions.

\footnotetext{
${ }^{1}$ Др сц. Лазар Јанић, Висока здравствена школа струковних студија у Београду, Србија.
} 


\section{УВОД}

истемски развој теорије управљања може се пратити два века уназад, али су за потребе одређења појма управљања доминантне школе мишљења према којима се управљање мора класификовати према својеврсним оквирима, тзв. приступима како би се могао покрити најшири круг теоретичара, као и сви актуелни углови посматрања. Тако ће фокус рада бити на прогресији идеја које су унапређивале организационе перформансе.

Предмет истраживања рада је управљање пословним процесима, управљање наставно-образовним / научно-истраживачким процесима, управљање ресурсима, управљање квалитетом, управљање ризицима, управљање информацијама и управљање знањем. Уз разграничење предметних појмова, рад као ужи предмет истраживања има управљање поменутим процесима у академским високошколским установама и струковним високошколским установама.

\section{ОДРЕЂЕНЕ ПОЈМА УПРАВЉАЫА}

Аутори тзв. класичног приступа о организацији размишљају у терминима сврхе и формалне структуре, са тежиштем на планирању рада, техничким захтевима, принципима управљања и претпоставци рационалног и логичног понашања. Анализа организације по овом моделу припада првој половини 20. века, пре свега кроз радове Тејлора, ${ }^{(1)}$ Фајола, Урвика, Мунија, Рајлија и Бреха. Наведени аутори видели су сврху организације као есенцијалну за разумевање њеног функционисања и метода којима се рад може унапредити. Идентификација општих циљева води разјашњењу циљева и одговорности на свим нивоима организације, што онда ствара ефектније структуре. Акценат је на управљању које дефинише области рада, задужења и одговорности, постизању специјализације и координације унутар организације. Суштина је у хијерар- хијском менаџменту и формалним организационим односима.

За ову теоријску школу унапређење организационе структуре је један од основних циљева управљања јер он подразумева и растућу ефикасност. Ту спадају још и значај принципа на којима се ствара организација и логичност њене структуре.

Поменути аутори били су заговорници нормативног стила управљања, а претходно наведени принципи су сет правила који нуде општа решења за уобичајене проблеме организације и менаџмента.

Класични аутори су најчешће критиковани по питању изостављања људског фактора и стварања организационе структуре у којој запослени немају слободу утицаја на сопствено радно окружење.

Сет принципа у управљању који су заступали, такође, био је подвргнут критици јер је предвиђао комплексне организационе системе са вишеструким циљевима. Иако доказано неефектан у пракси, класични приступ теорији управљања ипак је поставио основе за систематично сагледавање менаџмента и оставио неке још увек релевантне принципе, примењиве на готово све организације.

Даље теоријске школе управљања настојале су да докажу релевантност својих принципа у следећим правцима:

- одређених ситуационих варијабли у свакој индивидуалној организацији,

- психолошким и социјалним факторима повезаним са члановима организација.

Друга половина 20. века доноси и нове приступе теорији управљања, као што су структурализам, неохуманизам, системски приступ и сл.

Структуралистички приступ Макса Вебера $^{(2)}$ је спој структуралистичке и неформалних школа управљања, а заснива се на критици структурализма због уоченог недостатка адекватне теоретске позадине, исувише радикалне перспективе и занемаривања друштвене позадине и последица 
управљања. Вебер је сматрао да у теорији, али и пракси управљања, треба дати више простора односима формалних и неформалних аспеката организације и проучавању конфликта између потребе појединца и организације, између радника и менаџмента.

Приступ који је заснован на људским ресурсима развијао се у Америци после Велике депресије (1929), пре свега у правцу разматрања друштвених фактора у раду и понашања запослених у организацији. Урађена су истраживања која су емпиријски доказала да је задовољни радник продуктивнији и то је теорију менаџмента приближило осталим друштвеним дисциплинама, пре свега психологији. Нове идеје у теорији управљања брзо су прихваћене и фокус је окренут ка личном прилагођавању појединаца у оквиру радне организације, ефектима односа унутар тима и стиловима лидерства. Лидери су перципирани као стубови сваке организације. Успешност организације зависи од способности, предности и недостатака, као и тачних и погрешних потеза њеног лидера. ${ }^{(3)}$

Теоријски оквир овог приступа, који је доминантан и данас, базира се на раду Абрахама Маслова ${ }^{(4)}$ „Теорија људске мотивације“, у коме Маслов поставља оквир индивидуалног развоја и мотивације засноване на хијерархији људских потреба. Иако аутор свакако није замислио примену ове скале потреба на радно место, рад је имао значајан утицај на управљачки приступ мотивацији и дизајн рада организација како би се изашло у сусрет индивидуалним потребама запослених.

Међу најпознатијим теоретичарима неохуманистичког приступа управљању су Херцберг ${ }^{(5)}$ и Мекгрегор. ${ }^{(6)}$ Херцберг је издвојио два различита сета фактора која утичу на мотивацију и задовољство на послу. Један сет обухвата факторе чије одсуство изазива десатисфакцију, пре свега везаних за радно окружење. Ипак, да би се радници мотивисали да дају свој максимум, па- жњу треба посветити оним факторима који представљају мотиваторе и факторе раста. Мекгрегор сматра да је стил управљања одраз бриге о људској природи и понашању на послу. Сукцесори неохуманистичке теорије управљања су Ликерт, ${ }^{(7)}$ чије рад укључује истраживања различитих система управљања, Мекклиланд, ${ }^{(8)}$ с идејом о постизању мотивације, и Аргирис, ${ }^{(9)}$ који је разматрао ефекте формалне организације на појединца и психолошки развој у процесу самоактуелизације. Аргирисов најзначајнији допринос укључује рад на тзв. учећој организацији и ефективном лидерству.

Неохуманистички приступ је генерисао обимну литературу и истраживања не само поменутих аутора, већ и ширег круга аутора који су покушали да докажу или побију њихове идеје. То је довело до континуиране концентрације на области, као што су: организационо структурисање, динамика групе, задовољство послом, комуникација и партиципација, стилови лидерства и мотивација. Такође је довело до појачаног интересовања за значај интерперсоналних интеракција, узрока конфликата и препознавања проблема везаних за однос према радницима.

Системски приступ теорији управљања је скоријег датума, и фокусиран је на анализу организације као система са бројним унутрашњим повезаним подсистемима. За разлику од класичног приступа који се бавио организацијама без радника, а неохуманистички радницима без организаци$\mathrm{ja}$, системски приступ настоји да помири ова два приступа. Пажња је фокусирана на свеукупни рад организације и међувезе структуре и понашања, као и широк опсег варијабли унутар организације. Системски приступ охрабрује менаџере да сагледавају организације истовремено и као целине, али и као делове ширег окружења. Идеја је да активности било ког дела организације погађају све делове. Један од оснивача овог приступа је биолог Лудвиг фон Бертлан- 
$\phi и,{ }^{(10)}$ који је сматрао да се организација може посматрати као биолошки организам.

Боулдинг(11) је класификовао девет комплексних нивоа система развоја и знање потребно за развој сваког, с обзиром на то да су организације комплексни друштвени системи подложни променама. Аутор је сматрао да постоје велики јазови у теоријском и емпиријском знању о људским ресурсима и друштвеним организационим нивоима система, иако је теорија организационог понашања направила извесни помак напред. Боулдинг пословну организацију сматра отвореним системом у коме је присутна континуирана интеракција екстерним окружењем чији је део. Системски приступ сагледава организацију у њеном укупном окружењу и подразумева значај вишеструких канала њихове интеракције, а њу саму као целину, односно као збир интеракција између техничких и друштвених варијабли унутар система. Промене у једном сегменту, техничком или друштвеном, утицаће на друге делове и на систем у целини. Концепт организације као социо-технолошког система усмерава пажњу на трансформацију или конверзију самог процеса, на серију активности кроз које се управљачким техникама остварују организациони циљеви.

Социо-технолошки систем управљања се фокусира на интеракције између психолошких и друштвених фактора и потребу и захтеве људског дела организације и њених структурних и технолошких захтева. Значај оваквог приступа је данас значајнији него икада јер се људи морају сматрати у најмању руку једнаким приоритетом као и инвестиције у технологију.

Концепт социо-технолошких система обезбеђује повезаност између системског приступа и подтеорија као што је технолошки приступ. Аутори који су наклоњени технолошком детерминизму покушавају да ограниче генерализацију око организација и управљања и наглашавају ефекте различитих технологија на организационе струк- туре, радне групе и индивидуалне перформансе и задовољство запослених.

Ситуациони приступ обнавља идеје системског приступа и у фокус истраживања враћа на значај структуре које, тврди се, имају сигнификантан утицај на организационе перформансе. Наглашава се да не постоји оптимални модел управљања за све ситуације јер постоји огроман варијетет организационих структура и система управљања. Тако нпр. организација и њен успех зависе од природе задатака с којим је дизајнирана да се носи и природе утицаја окружења. Стога најоптималнија структура и систем управљања зависе од ситуација у којима се свака појединачна организација налази. Ситуациони приступ имплицира да теорије управљања не треба да теже најбољем начину управљања организацијама, већ да пруже увид у ситуационе и контекстуалне факторе који утичу на управљачке одлуке.

Системски приступ укључује издвајање оних функција управљања које директно утичу на постизање циљева организације и идентификацију главних подручја одлучивања у њеним подсистемима. Виђење организације као система подразумева потребу за добрим информацијама и каналима комуникације у циљу да се помогне ефективном доношењу одлука у организацији. Препознавање потребе за доношењем одлука је основа теорије одлука у којој је фокус пажње на управљачком одлучивању и томе како организационе процесе и информације користити у одлучивању.

Успешно управљање лежи у одговору на интерне и екстерне промене, што укључује разјашњавање циљева, спецификацију проблема и проналажење начина за имплементацију решења. Организација је овде виђена као информационо-процесна мрежа с великим бројем тачака одлучивања. Разумевање процеса одлучивања помаже да се разуме понашање у организацији. Фокус овог приступа је широк и могуће је идентификовати допринос многих аутора, од инжењера, 
математичара и економиста до психолога и теоретичара менаџмента. Бернард ${ }^{(12)}$ истиче потребу за кооперативним акцијама у организацијама. Он верује у способност људи да комуницирају и у њихову посвећеност и допринос достизању зацртаних циљева у кооперативном систему. Идеју је даље развијао Симон, ${ }^{(13)}$ који види менаџмент као смислено одлучивање, бави се доношењем одлука и како се тај процес може унапредити. Симон се, такође, противи виђењу човека као потпуно рационалног и предлаже модел ,административног човека“, који, за разлику од „економског човека“, задовољава, а не максимизује. Административни модел одлучивања тежи задовољавању заинтересованих страна пре него решавању проблема. Економски модел одлучивања, заснован на претпоставци рационалног понашања у одабиру познатих алтернатива у циљу да се максимизују циљеви, може се поставити насупрот бихевиоралног модела заснованог не на максимизовању циљева колико на краткорочној експедитивности, где се одлука доноси да би се избегао конфликт и остало у оквиру зацртаних граница циљева.

Социјална акција представља допринос социологије изучавању организација. Аутори овог правца настоје да сагледају организацију са становишта индивидуалних чланова, од којих сваки има своје сопствене циљеве и интерпретацију свог рада у виду сопствене сатисфакције и значаја који рад има за њега. Индивидуални циљеви и активности предузете да би се постигли ови циљеви су под утицајем индивидуалне перцепције ситуације. Ова теорија посматра индивидуалну дефиницију ситуације као основу за објашњење понашања запослених. Конфликт интереса се види као нормално понашање и као део организационог живота.

Према Силвермену, ${ }^{(14)}$ индивидуални приступ сам по себи, не обезбеђује теорију организације, али помаже да се разуме метод анализе друштвених односа унутар ор- ганизације. Социјална акција критикује раније приступе управљању организацијама као неуспешне у смислу објашњења и предикције индивидуалног понашања. Критицизам је тако усмерен на приступ који се фокусира на циљеве и потребе организације пре него на уважавање потреба њених индивидуалних чланова. Хуманистички приступ се критикује због свог фокуса на генерализоване теорије успешног управљања, групне психологије и општих потреба свих запослених. Технолошки приступ се критикује због процењеног осећаја алијенације технологије и радника, а системски приступ због недостатка истраживања индивидуалне оријентације чланова организације.

Значајан допринос приступу социјалне акције дао је Фокс, ${ }^{(15)}$ који у извештају под насловом „Донован извештај“ (Donovan Report) сугерише два основна начина перцепције индустријске организације - унитарни и плуралистички. У унитарном приступу организација се сагледава као тим са уобичајеним извором лојалности, једним фокусом напора и једним прихваћеним лидером. Плуралистички приступ види организацију као скуп конкурентских подгрупа с њиховом сопственом лојалношћу, циљевима и лидерима, а које ће сасвим сигурно једном доћи у конфликт.

Теорију људског понашања из перспективе акционог приступа управљању представила је Бови, ${ }^{(16)}$ сматрајући да теорија акције, системска теорија и ситуациона теорија нису нужно инкопатибилне у разумевању организације. По њеном мишљењу, потребно је преузети најбоље аспекте различитих приступа и комбиновати их у теорију која би обликовала и анализирала понашање великог броја запослених у организацијама. Њена теорија се заснива на три основна принципа који се могу сумирати у следећем: социологија се бави не само понашањем већ смисленом акцијом, одређена значења опстају кроз реафирмацију у акцији и акције воде променама које се могу 
применити на индивидуално понашање. Она представља четири концепта на којима се заснива широка база понашања у организацији:

- концепт улога - неопходан за анализу понашања у организацијама, објашњава истоветне акције различитих људи у сличним ситуацијама у организацијама и очекивања људи,

- концепт односа - потребан за објашњење модела интеракција међу људима и понашања која показују једни према другима,

- концепт структуре - односи међу члановима организације стварају моделе деловања који се могу назвати ,транзиционе друштвене структуре“. Друштвени и недруштвени фактори као што су платни системи, методе производње и сл., заједнички формирају бихевиоралне структуpe,

- концепт процеса - људско понашање може се анализирати у терминима процеса, дефинисаних као континуиране независне секвенце акција. Концепт процеса је неопходан да би се изучавао манир у којем организација прихвата промене у структури.

Указано је на неколико доминантних теорија управљања, али класификација може бити далеко обимнија. Тако новије категоризације у теорији управљања идентификују и приступе менаџменту, као што су: квантитативна анализа, математички модел, операциона истраживања и компјутерска технологија.

Постмодернистичке теорије управљања сматрају развој информација и технолошке ере својом основом. Аутори последњих деценија описују постмодерну организацију у терминима технолошког детерминизма, структуралне флексибилности, послова заснованих на тзв. мултитаскингу и комплексног запошљавања попут подангажмана и умрежавања. Постмодернистичке теорије управљања одбацују рационални систем- ски приступ у разумевању организације и управљања и не прихватају традиционална објашњења друштва и понашања. Високо флексибилне, слободног тока и флуидних структура, прилагодљиве променама и захтевима, нове организације захтевају постмодерне теорије управљања. Могућност било какве комплетне и кохерентне теорије управљања се тиме потпуно доводи у питање.

Милисављевић сматра да је менаџмент предуслов за опстанак, раст и развој сваког предузећа и установе, који се не исцрпљује само у доношењу пословних одлука већ укључује и предузимање акција на њиховом остваривању. ${ }^{(17)}$

\section{ПОЈАМ УПРАВЉАЫА У ВИСОКОМ ОБРАЗОВАНУ}

Према Приручнику за организационе процесе Масачусетског института за технологију (Massachusetts Institute of Technology), пословни процеси су „нестатичне, поновљиве секвенце догађаја које су често широко дистрибуиране у времену и простору, са двосмисленим границама. Редизајн или само опис пословних процеса захтева приступ који је осетљив на ове аспекте феномена". ${ }^{(18)}$ Управљање пословним процесима институција високог образовања је механизам класичног менаџмента привредног субјекта који треба да доведе до остварења визије, мисије, циљева и зацртаних резултата институције. Укратко, овде се говори о стварању вредности и комуникацијама. Сваки успешан однос заснива се на поверењу. Сви односи са потрошачима, добављачима и запосленима заснивају се на томе да људи могу да верују да ће привредни субјекат, односно у овом случају високошколска установа урадити оно што је обећала. Најдрагоценије вредности организације или појединца су репутација и углед које уживају код својих партнера (стејкхолдера). ${ }^{(19)}$ 
Управљање пословним процесима институција је континуиран процес у току којег се све активности плански усмеравају ка реализацији и евалуацији. Не постоји коначан списак пословних процеса јединствен за све организације, па ни високошколске, али постоје широко прихваћени алати за њихово утврђивање, међу којима су најважнији:

- Матрица испоруке вредности процеса / стејкхолдера (Process / Stakeholder Value delivery Matrix) - детектује и рангира значај процеса за све заинтересоване стране у пословању (кориснике), и

- Матрица истицања вредности (Salience / Worth Matrix) - утврђивање пословних процеса у које треба улагати јер стварају вредност.

Управљање наставно-образовним / научно-истраживачким процесима подразумева креирање и спровођење стратегије менаџмента са макронивоа грана (институције, универзитети) на микронивое (факултети, департмани, сектори, катедре) који иду у уситњавање до појединачних научно-истраживачких пројеката.

Управљање ресурсима у високошколским институцијама подразумева управљање људским ресурсима (њиховим компетенцијама, вештинама и процесом рада), производним ресурсима и информационим технологијама.

Систем квалитета високог образовања у Србији је регулисан Законом о високом образовању, ${ }^{(20)}$ пре свега кроз формирање Националног савета за високо образовање, потом Комисије за акредитацију и проверу квалитета, обезбеђивање квалитета високошколске установе, акредитацију, самовредновање, Конференцију универзитета, Конференцију академија струковних студија, студентске конференције и Министарство (чланови 9-23).

Квалитет према ИСО стандардима је степен испуњавања захтева корисника. На Слици 1 представљени су утицаји на ква- литет високошколског образовања, као и заинтересоване стране за квалитет виоскошколског образовања. Квалитет високог образовања се дефинише као:

- Квалитет високог образовања у ширем смислу - усаглашеност високог образовања (резултата, процеса и система) са потребама и захтевима корисника, циљевима, нормама и стандардима,

- Квалитет високог образовања у ужем смислу (квалитет припреме високообразованих стручњака) - усаглашеност припреме високообразованих стручњака (резултата, процеса) са потребама и захтевима (државе, друштва, послодаваца, тржишта знања, личности), циљевима, нормама и стандардима. ${ }^{(21)}$ 
Слика 1. Утицаји на квалитет високошколског образовања.

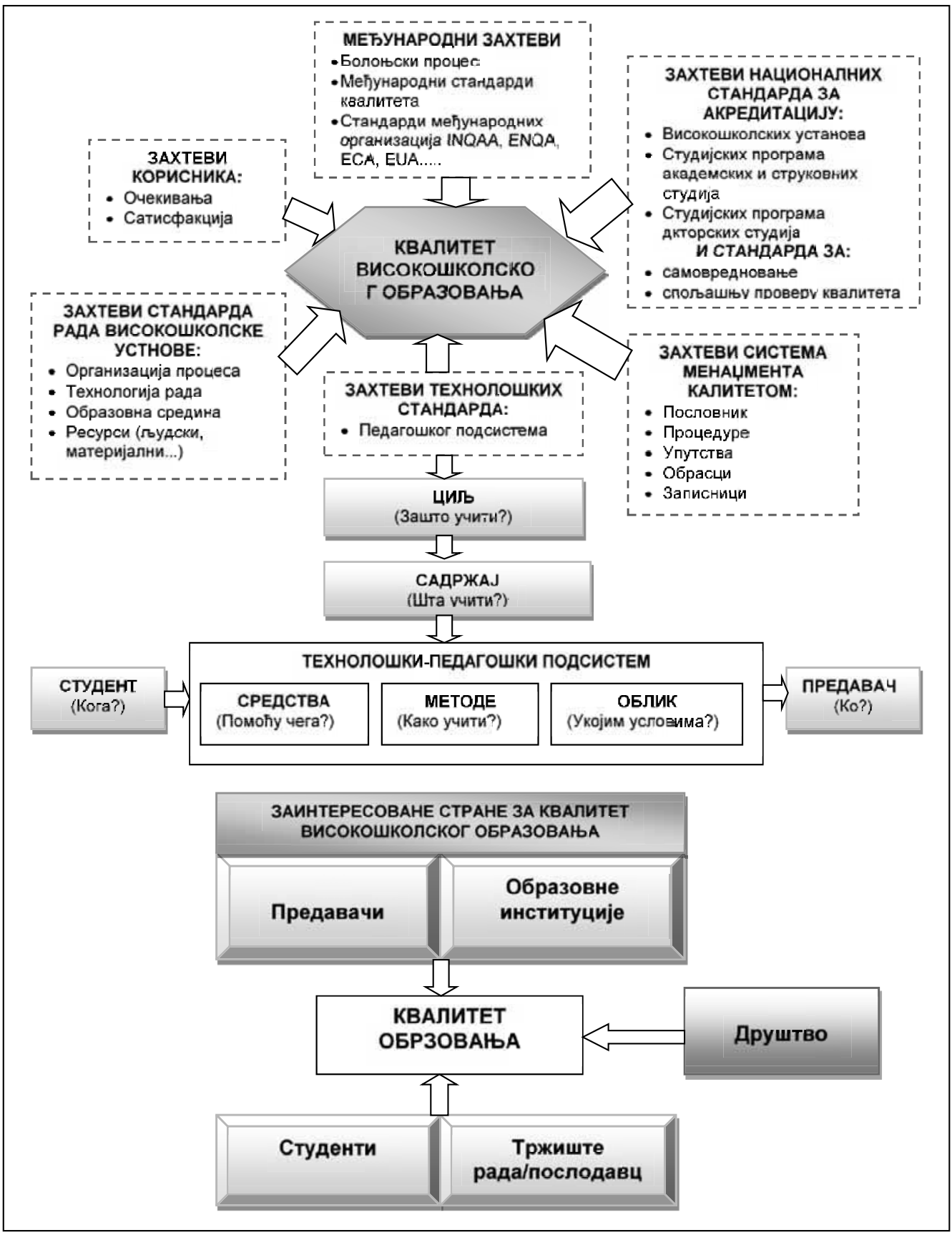

Извор: Лазић М. (2007) Систем квалитета - QMS у високом образовању. 34. Национална конференција о квалитету, Асоцијација за квалитет и стандардизацију Србије. Доступно на: http://www.cqm.rs/2007/pdf/34/05.pdf. Преузето: 5. 2. 2017. године.

Према Лазићу, аутору у смислу ИСО стандарда, филтери за одређивање квалитета којим управља менаџмент високошколске установе су квалитети: студијских програма, материјалне и ИТ подршке наставном процесу, наставног кадра, процеса образовања и обуке, као и квалитет исхода образовања - произведених кадрова за тржиште рада.
Захтеве које системи квалитета постављају пред управљачке структуре Лазић дефинише преко планирања квалитета, управљања квалитетом, обезбеђења квалитета и унапређења квалитета, што је представљено на Слици 2. 
Слика 2. Захтеви система квалитета.

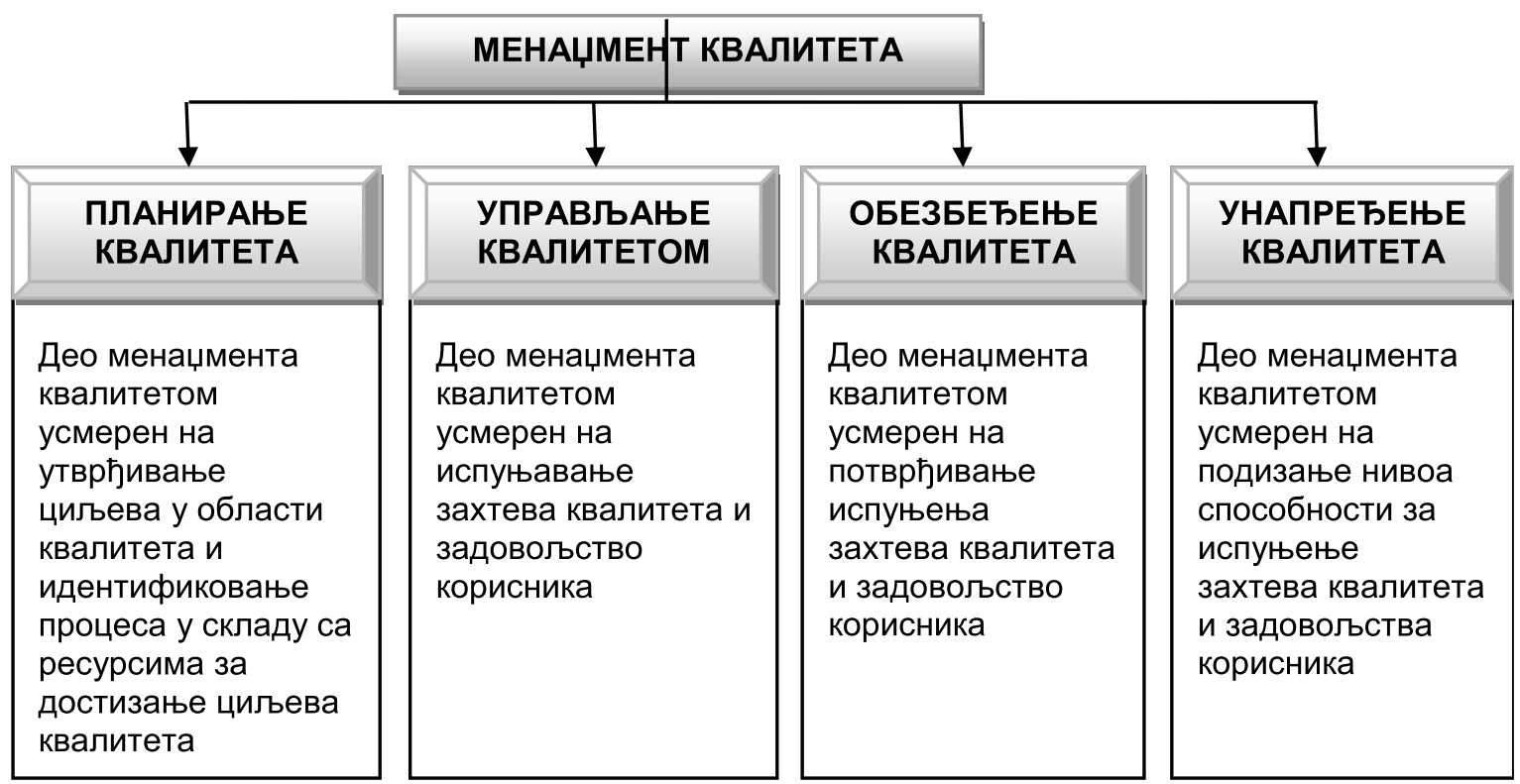

Извор: Лазић М. (2007) Систем квалитета - QMS у високом образовању. 34. Национална конференција о квалитету, Асоцијација за квалитет и стандардизацију Србије. Доступно на: http://www.cqm.rs/2007/ pdf/34/05.pdf. Преузето: 5. 2. 2017. године.

Управљање ризицима у високошколским установама је интегрални део стратешког менаџмента и стандарда ИСО 31000, који ризик дефинише као „утицај несигурности на циљеве“, при чему се под несигурношћу подразумева „стање или услове који укључују дефицит информација и воде неадекватном или некомплетном знању или разумевању“.(22)

Управљање ризиком подразумева одређивање слабих тачака свих организацијских сегмената, идентификовање критичних тачака ризика, као и управљање последицама ризика. Јановац идентификује следеће потенцијалне ризике у сектору високог образовања:

- „промене тренда интересовања корисника услуге високог образовања,

- активности које предузимају конкуренти,

- промене у монетарној сфери (инфлациja, дефлација, девалвација, и др.),

- промене у кредитној политици (експанзија или рестрикција кредита),

- промене у локалној самоуправи (приватизација, и реструктурирање предузећа),
- социјалне и друштвене промене (промене демографског карактера),

• промене у законској регулативи“. (23)

Управљање информацијама захтева најпре да се направи разлика између података и информација. Наиме, подаци су кодификоване поруке које могу бити релавантне или ирелевантне за одређену институцију. Уколико су релавантне, сматрају се информацијама, али, да би то постали, морају бити стављени у одређени контекст. Изолована информација, без контекста, не може се користити да би се предвиделе акције, последице и њихова међузависност. Информациони системи у високошколским институцијама су део управљачког процеса у два аспекта:

- као подршка администрацији установе (прикупљање и класификација података о студентима), и

- као систем подршке процесу одлучивања менаџмента институције.

Управљање знањем je, за разлику од претходних облика управљања, карактеристично управо за образовне 
институције. Институције високог образовања су сачињене од експерата свих могућих поља (научних области) који продукују и чувају различита знања. Као „организације знања“, високошколске институције морају да унапреде менаџмент знања како би се оно користило како интерно, за развој установе, тако и екстерно, у заједници у којој она функционише.

Менаџмент знања може се дефинисати као процес који формира факторе детерминанти за запослене, развој и систематизацију знања у организацији на најбољи могући начин, као би се остварили стратешки циљеви организације. Знање је флуидне природе и њиме се не може управљати на класичан, хијерархијски начин, механички. Појединци сами одлучују како да стекну, користе и развијају своја знања, тако да принцип класичног менаџмента овде није ефектан како би се осигурало ефективно дељење и развој знања.

\section{УПРАВЉАЫЕ АКАДЕМСКИМ ВИСОКОШКОЛСКИМ УСТАНОВАМА}

„Високошколска установа представља динамичан, савремен, ефикасан и функционалан систем, прилагодљив променама и потребама друштва. У контексту савременог приступа управљања установом, који је окренут ка ефективности и ефикасности управљачке функције, установа треба да успостави организациону структуру и систем управљања који обезбеђује постизање задатака и циљева високообразовне установе. “(24)

Према Закону о високом образовању Републике Србије ${ }^{(25)}$ делатност високог образовања обављају: универзитети, факултети односно уметничке академије, високе школе и високе школе струковних студија, академије струковних студија. Према члану 46 истог закона, унутрашње уређење организације, нивоа менаџмента и његових задужења, регулише се Статутом високошколске установе, мада сам закон стандардизује следеће органе: „орган управљања (савет), потом орган пословођења (универзитета - ректор, факултета - декан, академије струковних студија - председник, високе школе и високе школе струковних студија директор), стручне органе (сенат/научнонаставно веће) и студентски парламент“. Из наведеног јасно је да се ради о вертикалној хијерархији управљања, чија хоризонтална организација почива на систему управљања квалитетом. Овакав „организациони систем састоји из више подсистема: подсистем наставног процеса, подсистем ненаставне подршке, подсистем истраживања и развоја, подсистем маркетинга, итд. и сваки од ових подсистема могу се састојати из више делова који функционишу независно, али истовремено и синергетски“.

Друштвено окружење високошколских установа је високо динамично и променљиво, тако да се менаџмент мора заснивати на сталном праћењу промена, предвићању и побољшавању тржишних перформанси. Основа за праћење пулса тржишта су истраживања ставова и захтева корисника (студената) и других стејкхолдера (пре свега тржишта рада и привредних субјеката). Досадашњим системом управљања високошколским установама у Србији улога менаџмента је бирократизована, док промене начина размишљања и тржишног понашања захтевају лидерски тип управљања. „За успех једног факултета од кључног значаја је улога декана, као менаџера факултета. Међутим, деканима су све више потребне лидерске компетенције као што су инспирисање промена, мотивисање запослених на свим нивоима за промене, комуникација са академском и широм заједницом и многе друге“, сматрају Илић-Косановић и др. ${ }^{(26)}$

Рамсден ${ }^{(27)}$ сматра да на промену менаџмента у образовању утичу пре свих фактори окружења, као што су - омасовљење високог образовања, раст масе знања, ограничавање 
јавног финансирања, растуће инсистирање на другачијем исходу образовања (вештине испред знања), притисци за профитом и сл. Бриман ${ }^{(28)}$ полази од становишта да декани/ управници/директори у високом образовању морају поседовати развијене вештине комуникације и решавања конфликта, јер су управо оне кључне у успостављању правца развоја установе, управљања људским ресурсима, унапређењу колегијалности, улоге узора и унапређења циљева институције.

Говорећи о балансу академског лидерства и пословне ефикасности у управљању високошколским институцијама, Гленис Дру ${ }^{(29)}$ наглашава да су „Универзитети данас рањиви на ризик и захтевају исти модел управљања и стратегија менаџмента ризика као и њихови пословни суседи“ јер одговарају истовремено и за перформансе квалитета и за спровођење закона у области образовања. Дру се у овим тврдњама ослања на парадоксалну ситуацију у коју тржиште ставља образовне институције захтевајући да своје активности прошире у комерцијална поља, док их истовремено пракса и сама смисао постојања у томе ограничавају. Укратко, од њих се очекује да се фокусирају на исходе учења, акредитације и систем квалитета, док се истовремено од њих захтева да своју релативно бирократску структуру прилагоде предузетништву и тржишту.

Руководећи кадрови ових институција се, по закону, бирају из редова наставног особља које, без обзира на степен образовања и стручности у својим пољима, не припада предузетничком кадру и није бирано по критеријуму тржишног искуства и успешности. Парадокс положаја менаџмента у високом образовању тиме је још дубљи. Приватне високошколске институције у својим регулаторним актима понегде имају професионални управљачки кадар (нпр. извршни директори, директори маркетинга и сл.), док у државним установама ни тога нема. Очекује се, дакле, да неко ко се читавог живота припремао за наставни и научно-истраживачки рад, по избору у ру- ководеће структуре учини обрт у менаџер/ лидера који одлично познаје економске и друштвене приоритете. Балансирајући између захтева за константно растућим управљачким компетенцијама и унапређењем научног знања, високошколске установе су у процепу између два света без много додирних тачака - академског и бизниса. Стога је исправно закључити да су пред менаџментом универзитета, факултета и високих школа нови изазови прилагођавања будућим захтевима за стратешку трансформацију у комплексном и динамичном окружењу.

Промене у оријентацији високошколских институција захтевају од управљачких структура јако сложен опис посла, између осталог и да: одржавају ниво изврсности, осигурају средства финансирања, баве се људским ресурсима, комуницирају, делују консултативно, управљају буџетом, креирају стратешке планове, управљају променама, подржавају научно напредовање наставног кадра и др., односно да помире системске и административне функције. Рамсден ${ }^{(30)}$ сматра да у оваквим ситуацијама све зависи од личног капацитета менаџера да уче. Овако комплексна улога не одговара постојећем моделу управљања високошколским институцијама у Србији, који се заснива на двојном моделу управљања, тј. државне институције имају застарели облик менаџмента, док су приватне окренуте тржишту, али по истој легислативи, што их у основи ограничава. Дакле, у процесу трансформације менаџмента у високом образовању потребна је најпре системска подршка, којом ће се подржати развој управљачких улога и обезбедити систем припреме за будуће генерације академских менаџера.

\section{УПРАВЉАЫЕ СТРУКОВНИМ ВИСОКОШКОЛСКИМ УСТАНОВАМА}

Према Закону о високом образовању Републике Србије ${ }^{(31)}$, у области струковних студија постоји: академија струковних 
студија, висока школа, као и висока школа струковних студија. Када је у питању академија струковних студија, њен управљачки орган је председник, док ту функцију спроводи директор високе школе и високе школе струковних студија.

Кад је реч о тржишном прилагођавању високошколских установа, закључак је да струковне студије имају одређену предност над универзитетима и факултетима. Наиме, ове установе образују стручне кадрове према потребама тржишта рада, имају конкретније исходе учења и флексибилније су у погледу промена програма и организације. Међутим, исти је законски оквир, што органе управљања у њима доводи у исту ситуацију као и на универзитетима/факултетима. Такође, струковно образовање доживело је у протеклој деценији највеће трансформације о образовном систему Србије, пре свега у подизању на степен високог школства, продужења дужине школовања и прелазак на болоњски систем. Реформа је тако учињена и на институционалном, кадровском и техничком нивоу. Усвајањем „Стратегије о развоју образовања у Републици Србији до 2020. године“, (32) дат је нови оквир будућег развоја струковног образовања. Тако су високе струковне студије обликоване да се лакше фокусирају на своју друштвену улогу, трансформишу своју структуру, мисију, процесе и програме како би што боље одговориле на потребе друштва, док су универзитети и факултети задржали круту структуру и остали у свом извороном облику без обзира на промене у окружењу.

Менаџмент струковних високошколских институција је, поред тога, у ближем контакту с тржиштем рада, тј. организацијама за које школује кадрове, што због радне праксе која је интегрисани део наставних планова и програма, што због веће адаптибилности на промене у друштву, економији и привреди. У овом облику управљања најважније је усагласити људе и друге ресурсе, али их и стратешки повезати у систем који се заснива на стручности и комуникацији, како би се постигао јасан, разумљив, кохерентан и на задатим вредностима заснован циљ. Нпр., ако је стратешки циљ менаџмента партнерство с привредом, систем управљања установом мора бити отворен за практичну сарадњу, али не на занемарујући академски ниво. Овакав циљ подразумева управљање флексибилном уписном политиком, усклађивање заједничких вредности, управљање моделима исхода учења и промовисање компетенција и вештина студената. Укратко, менаџмент високих струковних студија најближи је пословном менаџменту од свих високошколских нивоа управе.

\section{ЗАКЉУЧАК}

Теоријски преглед литературе и теорија управљања у високом образовању захтева разграничење појмова које обухвата менаџмент у високом образовању: управљање пословним процесима, управљање наставно-образовним / научно-истраживачким процесима, управљање ресурсима, управљање квалитетом, управљање ризицима, управљање информацијама и управљање знањем.

Промене, без обзира на то када се и како догоде, имају велики утицај на то како ће високошколске установе радити и каква ће им конкурентност бити. Логично је претпоставити да принципе тржишног пословања чека споро и тешко имплементирање у оквиру државних универзитета, тако да би управо високе струковне студије могле бити покретач процеса тржишног прилагођавања високог образовања. 


\section{ЛИТЕРАТУРА}

1. Taylor FW. The Principles of Scientific Management. London: Harper \& Brothers, 1911.

2. Weber M. Essays in Sociology. New York: Roudedge, 2009.

3. Лојић Р, Базић М, Талијан М. Утицај емоционалне интелигенције на развој лидерства. Војно дело 2015; 67(2): 263-278.

4. Maslow HA. A theory of Human Motivation. Psychological Review, 1943; 50: 370-396.

5. Herzberg F. The Motivation to Work. New York: Wiley, 1959.

6. McGregor D. The Human Side of Enterprise. Harmondsworth: Penguin Books, 1987.

7. Likert R. New patterns of management. New York: McGraw-Hill, 1961.

8. McClelland DC, Burnham DH. Power is the great motivator. Hardvard Business Review, 1976; 54(2): 100-110.

9. Argyris C. On organizational learning. Cambridge: Blackwell Pyblishers, 1992.

10. Ludwig von Bertalenffy K. General system theory - A new approach to unity of science. Human Biology, 1951; 23(4): 303-361.

11. Boulding K. General Systems Theory

- The Skeleton of Science. Management

Science, 1956; 2(3): 197-208.

12. Barnard CI. Organization and

Management: Selected Papers. Cambridge: Harvard University Press, 1948.

13. Herber AS. Theories of DecisionMaking in Economics and Behavioral Science. The American Economic Review, 1959; 49(3): 253-283.

14. Silverman D. The Theory of Organisations. London: Heinemann, 1970.

15. Banks RF. The Reform of British Industrial Relations: The Donovan Report and the Labour Government's
Policy Proposals. Relations industrielles / Industrial Relations, 1969; 24(2): 333-382.

16. Bowey AM. The Sociology of Organisations. London: Hodder \& Stoughton, 1976.

17. Милисављевић М. Стратегијски менаџмент: анализа, избор, промена. ЦИД Економског факултета у Београду. Београд, 2012; стр. 15.

18. Brian T, Pentland CS, Osborn GW, Luconi F. Useful Descriptions of Organizational Processes: Collecting Data for the Process Handbook. Massachusetts: Massachusetts Institute of Technology, 1999.

19. Базић М. Пословна комуникација - савремени пут до успеха. Мегатренд универзитет, Беорад, 2009; стр. 74-77.

20. Закон о високом образовању. Сл. гласник РС, 88/2017.

21. Лазић М. Систем квалитета - QMS у високом образовању. 34. Национална конференција о квалитету, Асоцијација за квалитет и стандардизацију Србије. Доступно на: http://www.cqm.rs/2007/ pdf/34/05.pdf. Преузето: 5. 2. 2017. године.

22. ISO 31000: 2009 Risk management dictionary. Доступно на: http://www. praxiom.com/iso-31000-terms.htm. Преузето: 5. 2. 2017. године.

23. Јановац Т. Унапређење квалитета високошколске установе на основу критеријума потреба корисника. Факултет за примењени менаџмент, економију и финансије, Београд, 2014; стр. 67.

24. Јановац Т, Вукајловић Ђ, Стојановић К. Примена концепта интегрисаног система менаџмента у високообразовној установи, Техника-Квалитет ИМС, стандардизација и метрологија, 2015; 15(5): 893-899.

25. Закон о високом образовању. Сл. гласник, 88/17. 
26. Илић-Косановић Т, Томашевић В, Васовић С. Лидерство у управљачким процесима високог образовања: квалитативна анализа. 2015, 10. децембар; 27-34. У: ЛИМЕН конференција, Београд.

27. Ramsden P. Managing the Effective University. Higher Education Research and Development, 1998; 17(3): 347-370.

28. Bryman A. Effective Leadership in Higher Education Summary of findings. University of Leicester: School of Management, 2007.
29. Drew G. Balancing Academic Advancement with Business Effectiveness? International journal of knowledge, culture and change management, 2006; 6(4): 117-125.

30. Ramsden P. Learning to lead in higher education. London: Routledge, 1998.

31. Закон о високом образовању. Сл. гласник РС 88/2017.

32. Стратегија развоја образовања у Србији до 2020. године. Сл. гласник PC 107/2012. Доступно на: http://www. vtsnis.edu.rs/StrategijaObrazovanja.pdf. Преузето: 5. 3. 2017.

Контакт: Др сц. Лазар Јанић, Висока здравствена школа струковних студија у Београду, Цара Душана 254, Земун, Београд, Србија, телефон: 063.89.31.293, e-mail lazarjanic@gmail.com 